\title{
A magasabb vérlemezkeszám mint a fej-nyak tumoros betegek túléléssel kapcsolatos esetleges prognosztikai faktora
}

\author{
Szilasi Zsuzsanna dr. ${ }^{1}$ - Jósa Valéria dr. ${ }^{2}$ \\ Zrubka Zsombor dr. ${ }^{3}$ - Mezei Tünde dr. ${ }^{4}$ - Merkel Keresztély dr. ${ }^{5}$ \\ Helfferich Frigyes dr. ${ }^{1}$ - Baranyai Zsolt dr. ${ }^{6}$ \\ ${ }^{1}$ Magyar Honvédség Egészségügyi Központ, Fül-Orr-Gégészeti és Fej-Nyaksebészeti Osztály, Budapest \\ ${ }^{2} J a h n$ Ferenc Dél-pesti Kórház, Fül-Orr-Gégészeti és Fej-Nyaksebészeti Osztály, Budapest \\ ${ }^{3}$ Budapesti Corvinus Egyetem, Egészségügyi Közgazdaságtan Tanszék, Budapest \\ ${ }^{4}$ Jahn Ferenc Dél-pesti Kórház, Urológiai Osztály, Budapest \\ ${ }^{5}$ Szent Imre Kórház, Sebészeti Osztály, Budapest \\ ${ }^{6}$ Semmelweis Egyetem, Általános Orostudományi Kar, I. Sebészeti Klinika, Budapest
}

\begin{abstract}
Bevezetés: Régóta ismert, hogy a daganatokhoz társuló emelkedett vérlemezkeszám rosszabb túléléssel társul. Fejnyak tumoros betegek esetében kevés információ áll rendelkezésünkre ezzel az összefüggéssel kapcsolatban.

Célkitüzés: Vizsgálatunk célja a fej-nyak daganatos betegek prognózisa és a thrombocytosis közötti összefüggés tanulmányozása volt.

Módszer: Különféle stádiumú és lokalizációjú, 312, fej-nyak tumoros beteg retrospektív adatait elemeztük. A műtét előtti vérlemezkeszámokat vizsgáltuk, a $300 \mathrm{G} / 1$ feletti értéket tekintettük emelkedett thrombocytaszámnak. A vérlemezkeszám és a túlélés közötti kapcsolatot Kaplan-Meier-módszerrel és multivariáns Cox-regresszióval elemeztük. Eredmények: Emelkedett thrombocytaszám mellett szignifikánsan rosszabb túlélést észleltünk (5 éves túlélés: $\mathrm{p}=$ 0,007, betegségmentes túlélés: $\mathrm{p}=0,192)$. Ez az összefüggés még akkor is fennállt, amikor multivariáns analízissel nemre, korra, stádiumra, differenciáltsági fokra, lokalizációra, valamint fehér- és vörösvérsejtszámra korrigáltuk az elemzést ( 5 éves túlélés: $p=0,027$ ). A különféle anatómiai lokalizációkban eltérő mértékben észleltünk $300 \mathrm{G} / \mathrm{l}$ feletti vérlemezkeszámot (algarat: 43,6\%, sub- és supraglottis: 35,8\%, szájüreg: 35,7\%, hangszalag: 22,5\%, szájgarat: 19\%, multiplex: 50\%), ez azonban nem befolyásolta szignifikánsan a túlélést ( $\mathrm{p}=0,603)$.

Következtetés: A daganathoz társuló thrombocytosis összefüggésbe hozható a fej-nyak tumoros betegek rosszabb túlélésével. Az egyes lokalizációkban talált különböző vérlemezkeszámok nem befolyásolják eltérő mértékben a túlélést.
\end{abstract}

Orv Hetil. 2021 ; 162(17): 676-682

Kulcsszavak: fej-nyak tumor, túlélés, prognózis, thrombocytosis, lokalizáció

\section{Elevated platelet count as a possible prognostic marker of survival in patients with head and neck tumours}

Introduction: The association between cancer-related thrombocytosis and worse survival has been described with a variety of solid neoplasms. However, only limited data are available on the prognostic significance of elevated platelet count in head and neck tumours.

Objective: We aimed to investigate the correlation between the survival of patients with head and neck cancer and thrombocytosis.

Method: We conducted an analysis of the data from 312 patients with head and neck squamous cell carcinoma of various stages and locations. Preoperative platelet counts were analysed; elevated platelet count was defined as 300 $\mathrm{G} / \mathrm{l}$ or higher. The influence of platelet count on survival was calculated with the Kaplan-Meier method as well as with multivariate Cox regression. 
Results: In patients with excessive thrombocytosis, survival was significantly worse (overall survival: $\mathrm{p}=0.007$, disease-free survival: $\mathrm{p}=0.192)$. This association remained significant even after adjusting the multivariate analysis for age, gender as well as tumour stage, grade, location, red and white blood cell count (overall survival: $\mathrm{p}=0.027$ ). The magnitude of thrombocytosis differed among tumours of different anatomical locations (hypopharynx: 43.6\%, suband supraglottis: $35.8 \%$, oral cavity: $35.7 \%$, vocal cord: $22.5 \%$, oropharynx: $19 \%$, multiple: $50 \%$ ), but this did not affect survival significantly $(\mathrm{p}=0.603)$.

Conclusion: Elevated platelet count may be related to a worse prognosis in head and neck squamous cell carcinoma patients. The impact of thrombocytosis does not vary with the anatomical location of the tumour.

Keywords: head and neck cancer, survival, prognosis, thrombocytosis, localization

Szilasi Zs, Jósa V, Zrubka Zs, Mezei T, Merkel K, Helfferich F, Baranyai Zs. [Elevated platelet count as a possible prognostic marker of survival in patients with head and neck tumours]. Orv Hetil. 2021; 162(17): 676-682.

(Beérkezett: 2020. október 1.; elfogadva: 2020. november 9.)

\section{Rövidítések}

$\mathrm{CI}=$ (confidence interval) konfidenciaintervallum; HNSCC $=$ (head and neck squamous cell carcinoma) fejnyaki laphámrák; $\mathrm{HR}$ = (hazard ratio) kockázati arány; $\mathrm{ROC}=$ (receiver operating characteristic) vevő múködési karakterisztika; TNM = tumor, nodus, metastasis

Évente kb. 650 ezer beteget diagnosztizálnak világszerte fej-nyaki laphámrákkal (HNSCC) [1]. Ez a kórkép a nyolcadik leggyakoribb halálok [2], a rosszindulatú daganatok 6\%-a [3]. A betegség incidenciája nő, a diagnózist gyakran előrehaladott stádiumban állítják fel, és a túlélési adatok igen kedvezőtlenek, ezért ezen daganatok ellátása komoly kihívást jelent.

Az utóbbi időben egyre több szolid tumornál (colorectalis [4-7], gyomor [8,9], méhnyak [10], petefészek [11-13], hasnyálmirigy [14, 15], tüdő [16-18], emló [19]) igazolják, hogy a magasabb vérlemezkeszám roszszabb túléléssel és koraibb áttétképződéssel jár.

Azt is leírták, hogy a fej-nyak daganatos betegek kezelés előtti vérlemezkeszáma alkalmas lehet a túlélés becslésére [20,21], a kapott eredmények azonban nem egyértelműek. Tanulmányunk során hosszú utánkövetéssel, különféle stádiumú szájüregi, garat- és gégedaganatban szenvedő betegek kezelés előtti vérlemezkeszámának prognosztikai jelentőségét vizsgáltuk.

\section{Módszer}

Vizsgálatunkban retrospektív módon az Uzsoki Utcai Kórház és a Magyar Honvédség Egészségügyi Központ 2000 és 2014 között kezelt, különféle stádiumú primer szájüregi, garat- és gégetumoros kórképben szenvedő betegeinek klinikai adatait elemeztük. Vizsgálatunkba szövettanilag igazolt planocellularis carcinoma miatt kezelt betegeket válogattunk be. A kezelés előtt legfeljebb egy hónappal készült laboratóriumi eredményeket elemeztük. A kizárás kritériumai a következők voltak: mü- tét utáni residualis tumor, szinkrón egyéb tumor, gyulladásos állapotok (pharyngocutan sipoly, pneumonia, sebgyulladás, tályog, epehólyag-gyulladás, branülgyulladás, endocarditis, húgyúti fertőzés, Crohn-betegség, colitis ulcerosa stb.), thrombemboliás szövődmények (mélyvénás thrombosis, tüdőembolia, szívinfarktus) és szteroidterápia. A thrombocytaaggregáció-gátló gyógyszert kapó betegeknél ez a kezelés a mütét miatt felfüggesztésre került. A stádiummeghatározást az American Joint Committee on Cancer 7. TNM-beosztása alapján végeztük. A teljes túlélés a kezelés időpontjától bármely okból bekövetkező halálozásig, illetve az utolsó észlelés dátumáig terjedt. A betegségmentes túlélést pedig a kezelés időpontjától a recidíva észlelésének időpontjáig számoltuk. A túlélési adatokat a Belügyminisztérium népességnyilvántartó adatbázisából lekérdezett információk alapján pontosítottuk.

\section{Statisztikai számitás}

A populáció jellemzőit leíró módszerekkel elemeztük, a normál eloszlású adatokat átlaggal és szórással, a nem normál eloszlású adatokat a mediánnal és interkvartilis tartománnyal jellemeztük. A betegek alcsoportjai közötti összefüggést kereszttáblamódszerrel és nemparametrikus tesztekkel (Wilcoxon-féle 'rank-sum test' [rangöszszegpróba], Kruskall-Wallis-próba) vizsgáltuk.

A következőképpen határoztuk meg az optimális 'cutoff' (küszöb-) értéket: logisztikus regressziós modelleket alkalmaztunk, függő változóként 3 éves túlélési statusszal és cut-off értékekkel a teljes vérlemezke-tartományból 10-re kerekítve. Kiszámítottuk minden cut-off értékre a 'receiver operating characteristic' (ROC) görbe alatti területet, és a ROC alatti legnagyobb terület alapján választottuk ki az optimális cut-off értéket. Ezzel a módszerrel a 300 G/l-t választottuk cut-off értéknek. A vérlemezkeszám küszöbértéke alatti és feletti betegek túlélését a 'log-rank' teszt segítségével elemeztük, és Kaplan-Meier-féle túlélési függvénnyel ábrázoltuk. 
Az 5 éves teljes túlélést és a betegségmentes túlélést többváltozós Cox-féle arányos kockázati regressziós modellekkel elemeztük, a vérlemezkéket folytonos és kategóriás diszkrét változókként kezelve. A többkategóriás diszkrét változók együttes hatását a Wald-teszttel vizsgáltuk. A Cox-modellek érvényességének feltételeit: az arányos kockázatot (proportional hazard) a Grambsch \& Therneau-féle 'score' teszttel [22], a modellek illeszkedését (goodness of fit) 4 rizikó-kvartilis tartományban a May \& Hosmer-féle teszttel ellenőriztük. Minden számítást a Stata 14.2 statisztikai programmal (StataCorp, College Station, TX, Amerikai Egyesült Államok) végeztünk [23].

\section{Eredmények}

A fenti kritériumok miatt 368 páciensből 56-ot kellett kizárnunk. A vérlemezkeszám és a teljes túlélés adatai 312, míg a betegségmentes túlélés számolásához szükséges információ 299 betegnél volt ismert (95,8\%). A medián utánkövetési idő 42,9 hónap volt $(4,9-161,0)$, és 134-en hunytak el az utánkövetés során $(42,9 \%)$. Nem a tumor volt a közvetlen halálok 31 esetben $(23,3 \%)$. Recidíva 132 (42,3\%) betegnél lépett fel. A medián túlélés 88,6 hónap (95\% CI: 71,8-124,2), a medián betegségmentes túlélés pedig 67,6 hónap (95\% CI: 37,8-87,0) volt.

A tumorlokalizációk a következők voltak: algarat, szájgarat, szájüreg, sub- és supraglottis, hangszalagok, valamint multiplex lokalizáció (1. táblázat).

226 páciensnél $(72,4 \%)$ mútét volt a primer kezelés, sugárkezelés és kemoterápia 46 betegnél (14,7\%), és sugárkezelés 40 esetben $(12,8 \%)$. Összesen $266(85,3 \%)$, $125(40,1 \%)$ és $111(35,6 \%)$ beteg kapott mútétet, kemoterápiát és sugárkezelést.

A medián vérlemeszkeszám $265 \mathrm{G} / 1$ volt. A vérlemezkeszám eltért a T- és N-statustól, a TNM-stádiumtól és a primer tumor lokalizációjától függóen $(\mathrm{p}=0,015$, $\mathrm{p}<0,001, \mathrm{p}=0,031, \mathrm{p}=0,025)$.

A betegek medián túlélése $<300 \mathrm{G} / 1$ vagy $\geq 300 \mathrm{G} / 1$ vérlemezkeszámmal 98,7 hónap (95\% CI: 80,7-124,4)

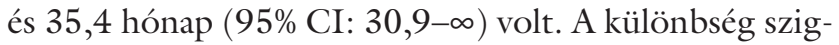
nifikáns volt $\left(\log\right.$-rank test $\left.\chi_{(\mathrm{df}=1)}^{2}=7,20, \mathrm{p}=0,007\right)$ (1. ábra).

1. táblázat |A betegek jellemzői a tumorlokalizáció alapján

\begin{tabular}{|c|c|c|c|c|c|c|c|c|c|}
\hline & & Algarat & Szájgarat & Szájüreg & $\begin{array}{l}\text { Sub- és } \\
\text { supraglottis }\end{array}$ & Multiplex & Hangszalag & Teljes & $\mathrm{p}$ \\
\hline & & No. $(\%)$ & No. (\%) & No. (\%) & No. (\%) & No. (\%) & No. $(\%)$ & No. (\%) & \\
\hline Teljes & & 110 & 42 & 14 & 67 & 8 & 71 & 312 & \\
\hline \multirow[t]{4}{*}{ Primer tumor $(\mathrm{T})$} & 1 & $11(10)$ & $11(26,2)$ & $7(50)$ & $8(11,9)$ & $1(12,5)$ & $26(36,6)$ & $64(20,5)$ & \multirow[t]{4}{*}{$<0,001$} \\
\hline & 2 & $24(21,8)$ & $17(40,5)$ & $5(35,7)$ & $32(47,8)$ & $0(0)$ & $18(25,4)$ & $96(30,8)$ & \\
\hline & 3 & $57(51,8)$ & $14(33,3)$ & $1(7,1)$ & $15(22,4)$ & $4(50)$ & $13(18,3)$ & $104(33,3)$ & \\
\hline & 4 & $18(16,4)$ & $0(0)$ & $1(7,1)$ & $12(17,9)$ & $3(37,5)$ & $14(19,7)$ & $48(15,4)$ & \\
\hline \multirow[t]{4}{*}{ Nyirokcsomó (N) } & 0 & $32(29,1)$ & $10(23,8)$ & $11(78,6)$ & $33(49,3)$ & $3(37,5)$ & $66(93)$ & $155(49,7)$ & \multirow[t]{4}{*}{$<0,001$} \\
\hline & 1 & $30(27,3)$ & $15(35,7)$ & $1(7,1)$ & $15(22,4)$ & $3(37,5)$ & $1(1,4)$ & $65(20,8)$ & \\
\hline & 2 & $43(39,1)$ & $16(38,1)$ & $2(14,3)$ & $19(28,4)$ & $1(12,5)$ & $4(5,6)$ & $85(27,2)$ & \\
\hline & 3 & $5(4,5)$ & $1(2,4)$ & $0(0)$ & $0(0)$ & $1(12,5)$ & $0(0)$ & $7(2,2)$ & \\
\hline \multirow[t]{2}{*}{ Metastasis (M) } & 0 & $110(100)$ & $42(100)$ & $14(100)$ & $67(100)$ & $8(100)$ & $71(100)$ & $312(100)$ & \multirow[t]{2}{*}{ NA } \\
\hline & 1 & $0(0)$ & $0(0)$ & $0(0)$ & $0(0)$ & $0(0)$ & $0(0)$ & $0(0)$ & \\
\hline \multirow[t]{4}{*}{ Stádium } & 1 & $3(2,7)$ & $4(9,5)$ & $5(35,7)$ & $6(9)$ & $0(0)$ & $27(38)$ & $45(14,4)$ & \multirow[t]{4}{*}{$<0,001$} \\
\hline & 2 & $10(9,1)$ & $5(11,9)$ & $4(28,6)$ & $15(22,4)$ & $0(0)$ & $18(25,4)$ & $52(16,7)$ & \\
\hline & 3 & $41(37,3)$ & $16(38,1)$ & $2(14,3)$ & $19(28,4)$ & $3(37,5)$ & $12(16,9)$ & $93(29,8)$ & \\
\hline & 4 & $56(50,9)$ & $17(40,5)$ & $3(21,4)$ & $27(40,3)$ & $5(62,5)$ & $14(19,7)$ & $122(39,1)$ & \\
\hline \multirow[t]{5}{*}{ Grade } & 1 & $6(5,5)$ & $1(2,4)$ & $2(14,3)$ & $5(7,5)$ & $0(0)$ & $12(16,9)$ & $26(8,3)$ & \multirow[t]{5}{*}{0,443} \\
\hline & 2 & $35(31,8)$ & $10(23,8)$ & $6(42,9)$ & $24(35,8)$ & $3(37,5)$ & $24(33,8)$ & $102(32,7)$ & \\
\hline & 3 & $33(30)$ & $11(26,2)$ & $2(14,3)$ & $17(25,4)$ & $2(25)$ & $17(23,9)$ & $82(26,3)$ & \\
\hline & 4 & $0(0)$ & $1(2,4)$ & $0(0)$ & $1(1,5)$ & $0(0)$ & $1(1,4)$ & $3(1)$ & \\
\hline & Ismeretlen & $36(32,7)$ & $19(45,2)$ & $4(28,6)$ & $20(29,9)$ & $3(37,5)$ & $17(23,9)$ & $99(31,7)$ & \\
\hline \multirow[t]{2}{*}{ Vérlemezkeszám >300 } & $\mathrm{Nem}$ & $62(56,4)$ & $34(81)$ & $9(64,3)$ & $43(64,2)$ & $4(50)$ & $55(77,5)$ & $207(66,3)$ & \multirow[t]{2}{*}{0,016} \\
\hline & Igen & $48(43,6)$ & $8(19)$ & $5(35,7)$ & $24(35,8)$ & $4(50)$ & $16(22,5)$ & $105(33,7)$ & \\
\hline 5 éves halálozás & Elhunyt & $48(43,6)$ & $16(38,1)$ & $3(21,4)$ & $30(44,8)$ & $4(50)$ & $14(19,7)$ & $115(36,9)$ & 0,019 * \\
\hline
\end{tabular}

${ }^{*} \log$-rank teszt $\chi_{(\mathrm{df}=1)}^{2}=13,47, \mathrm{p}=0,0193$ 


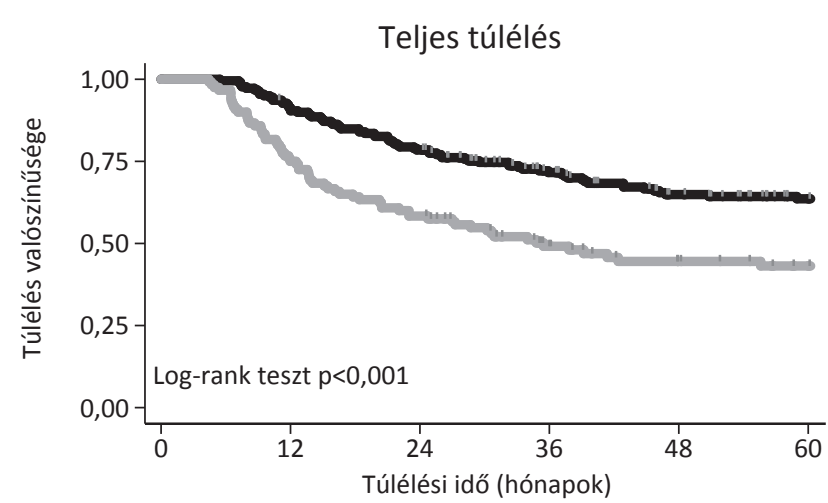

Veszélyeztetett betegek száma

\begin{tabular}{|c|c|c|c|c|c|}
\hline$P L T<300$ & 219 & 199 & 171 & 135 & 109 \\
\hline PLT $>=300$ & 120 & 90 & 70 & 47 & 35 \\
\hline
\end{tabular}

1. ábra $\mid$ A vérlemezkeszám és a teljes túlélés kapcsolata (Kaplan-Meierféle becslés)

PLT = vérlemezkeszám $(\mathrm{G} / \mathrm{l})$

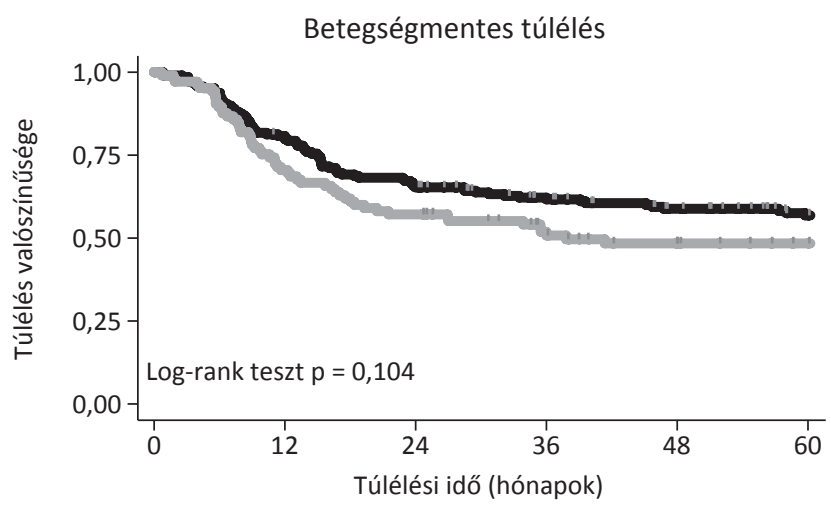

Veszélyeztetett betegek száma

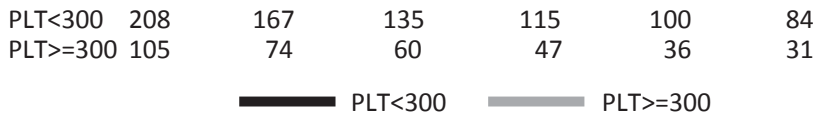

2. ábra $\mid$ A vérlemezkeszám és a betegségmentes túlélés kapcsolata (Kaplan-Meier-féle becslés)

PLT $=$ vérlemezkeszám $(\mathrm{G} / \mathrm{l})$

A medián betegségmentes túlélés 78,5 $(46,8-94,4)$ és $35,5(17,5-\infty)$ hónap volt a $<300 \mathrm{G} / 1$ vagy $\geq 300 \mathrm{G} / \mathrm{l}$ vérlemezkeszámmal. A különbség nem volt szignifikáns $\left(\log\right.$-rank test $\left.\chi_{(\mathrm{df}=1)}^{2}=1,70, \mathrm{p}=0,192\right)$ (2. ábra).

A vérlemezkeszám az 5 éves teljes túlélés szignifikáns előrejelzője volt a Cox-féle arányos kockázati regressziós analízissel, miután korra, nemre, tumorstádiumra és differenciáltsági fokra, valamint fehér- és vörösvérsejtszámra igazítottuk a modellt (2. táblázat). A kockázati arány (HR) 1,003 (95\% CI: $1,000-1,005, \mathrm{p}=0,027)$ volt. A kontrollváltozók közül a férfinem és az előrehaladott tumorstatus (3-4-es stádium) függött össze a halálozási kockázat szignifikáns emelkedésével. A tumor elhelyezkedése nem befolyásolta az 5 éves túlélést (Wald-teszt $\left.\chi_{(5)}{ }^{2}=3,63, \mathrm{p}=0,603\right)$.
A 300 G/l-es vérlemezkeszám cut-off értéket használva, az eredmények hasonlóak voltak, mint a vérlemezkeszámot folytonos változóként használó elemzésekben. $\mathrm{Az}$ emelkedett vérlemezkeszám közel kétszeres 5 éves halálozási kockázattal járt. A férfinem és az előrehaladott tumorstádium emelkedett, míg a magasabb vörösvérsejtszám csökkent 5 éves halálozási kockázattal járt. A tumor elhelyezkedése ebben a modellben sem befolyásolta az 5 éves túlélést (Wald-teszt $\left.\chi_{(5)}{ }^{2}=3,61, \mathrm{p}=0,607\right)$. A 300 G/1 fölötti vérlemezkeszám nem befolyásolta szignifikánsan a tumorrecidívát. A többváltozós Cox-regresszió nem mutatott összefüggést a betegségmentes túlélés és a modellben folytonos változóként szereplő vérlemezkeszám között $(\mathrm{p}=0,373)$.

\section{Megbeszélés}

Az emelkedett thrombocytaszám és a rosszabb túlélés közötti kapcsolat hátterében álló pontos patomechanizmus jelenleg még csak részben ismert. Különféle megfigyelésekról számoltak be: (a) A vérlemezkék fokozzák a tumor növekedését és az angiogenezist azáltal, hogy proangiogenetikus citokineket szecernálnak [24]. (b) A thrombocyták az áttétképződésben úgy vesznek részt, hogy a keringő tumorsejteket beborítva védik ezeket a mechanikus károsodásoktól $[25,26]$ és a szervezet immunválaszától $[27,28]$. A daganatsejtekhez adherált thrombocyták olyan citokineket (transzformáló növekedési faktor- $\beta$, thrombocytaeredetű növekedési faktor) termelnek, amelyek csökkentik a természetes ölősejtek aktivációját $[29,30]$. Ezenkívül a vérlemezkék nagy számban fejeznek ki I-es osztályú major hisztokompatibilitási komplexet. Azaz, a daganatsejtekhez tapadó thrombocyták hamis fenotípust mutatnak, és ezzel megzavarják a daganatosan átalakult sejt immunrendszer általi felismerését [29]. (c) Az egyik legújabb elmélet szerint a folyamat paraneoplasztikus útvonalon alapszik, amelynek kiinduló pontja, hogy a daganat a szérum interleukin-6-szintjének emelkedését okozza, ami a máj thrombopoetinelválasztásának fokozásával növeli a megakaryocytosist. A következmény thrombocytosis [31].

Sokan az emelkedett vérlemezkeszám és a túlélés hátterében az ún. másodlagos thrombocytosis lehetőségét vélik, ami reaktív válasz bizonyos állapotokra és kórképekre, például gyulladásra és anaemiára. Ennek elkerülésére zártuk ki azon pácienseket a vizsgálatból, akiknek gyulladásos szövődményük vagy betegségük volt. Tanulmányunkban összefüggést találtunk a csökkent vörösvérsejtszám és a túlélés között. Általában a daganatos betegek 30-50\%-ánál már a kezelés megkezdése előtt jelentkezik valamilyen mértékú vérszegénység, amely arány a daganatellenes kezelés hatására $50-70 \%$-ra is nóhet. Az anaemia nemcsak a betegek életminőségét rontja, hanem a kezelés hatékonyságát is csökkenti, ezáltal kedvezőtlen hatást gyakorolhat a gyógyulási és túlélési esélyekre $[32,33]$. Az viszont vitatott, hogy az anaemia állhat-e a megemelkedett thrombocytaszámnak és a da- 
2. táblázat |A betegadatok többváltozós elemzésének eredményei (Cox-féle regressziós analízis)

\begin{tabular}{|c|c|c|c|c|c|c|c|}
\hline \multirow[b]{3}{*}{ Változó } & \multirow[b]{3}{*}{ Kategória } & \multicolumn{6}{|c|}{ Halálozási kockázat } \\
\hline & & \multicolumn{3}{|c|}{$\begin{array}{l}\text { Vérlemezkeszám bináris változóként } \\
\geq 300 \mathrm{G} / 1 \text { cut-off esetén }\end{array}$} & \multicolumn{3}{|c|}{ Vérlemezkeszám folytonos változóként } \\
\hline & & Kockázati arány & $(95 \% \mathrm{CI})$ & $\mathrm{p}$ & Kockázati arány & $(95 \% \mathrm{CI})$ & $\mathrm{p}$ \\
\hline \multicolumn{2}{|c|}{ Vérlemezkeszám } & & & & $1,003^{*}$ & $(1,000-1,005)$ & 0,027 \\
\hline \multicolumn{2}{|c|}{ 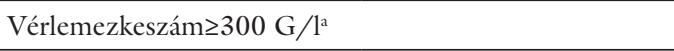 } & $1,933 * *$ & $(1,262-2,960)$ & 0,002 & & & \\
\hline $\mathrm{Nem}^{\mathrm{b}}$ & Férfi & $1,965 *$ & $(1,156-3,342)$ & 0,013 & $1,923^{*}$ & $(1,134-3,261)$ & 0,015 \\
\hline \multirow{3}{*}{ Stádium ${ }^{c}$} & 2. & 2,057 & $(0,722-5,866)$ & 0,177 & 1,998 & $(0,702-5,685)$ & 0,195 \\
\hline & 3. & $2,820 *$ & $(1,046-7,605)$ & 0,041 & $2,834^{*}$ & $(1,053-7,628)$ & 0,039 \\
\hline & 4. & $4,241 * *$ & $(1,591-11,30)$ & 0,004 & $4,139 * *$ & $(1,551-11,04)$ & 0,005 \\
\hline \multirow{4}{*}{ Gradus $^{\mathrm{d}}$} & 2. & 1,753 & $(0,670-4,590)$ & 0,253 & 1,540 & $(0,592-4,006)$ & 0,376 \\
\hline & 3. & 2,229 & $(0,846-5,872)$ & 0,105 & 1,864 & $(0,716-4,853)$ & 0,202 \\
\hline & 4. & 2,334 & $(0,257-21,16)$ & 0,451 & 1,941 & $(0,217-17,35)$ & 0,553 \\
\hline & Ismeretlen & 2,290 & $(0,881-5,949)$ & 0,089 & 2,042 & $(0,791-5,272)$ & 0,140 \\
\hline \multirow{5}{*}{ Lokalizáció $^{\mathrm{e}}$} & Szájgarat & 1,050 & $(0,582-1,896)$ & 0,871 & 0,991 & $(0,551-1,783)$ & 0,976 \\
\hline & Szájüreg & 0,891 & $(0,266-2,987)$ & 0,852 & 0,829 & $(0,247-2,777)$ & 0,761 \\
\hline & Sub- és supraglottis & 1,444 & $(0,894-2,332)$ & 0,133 & 1,392 & $(0,862-2,248)$ & 0,176 \\
\hline & Multiplex & 1,307 & $(0,456-3,745)$ & 0,619 & 1,309 & $(0,456-3,756)$ & 0,617 \\
\hline & Hangszalag & 0,851 & $(0,440-1,644)$ & 0,630 & 0,799 & $(0,413-1,547)$ & 0,506 \\
\hline \multicolumn{2}{|c|}{ Fehérvérsejtszám } & 0,931 & $(0,861-1,007)$ & 0,076 & 0,937 & $(0,864-1,015)$ & 0,112 \\
\hline \multicolumn{2}{|c|}{ Vörösvérsejtszám } & $0,664^{*}$ & $(0,443-0,995)$ & 0,047 & 0,689 & $(0,465-1,022)$ & 0,064 \\
\hline \multicolumn{2}{|l|}{ Esetszám } & 311 & & & 311 & & \\
\hline \multicolumn{2}{|c|}{ Arányos kockázati teszt - teljes (p) } & 0,125 & & & 0,125 & & \\
\hline \multicolumn{2}{|c|}{ Arányos kockázati teszt - vérlemezkeszám (p) } & & & & 0,962 & & \\
\hline \multicolumn{2}{|c|}{ Arányos kockázati teszt - vérlemezkeszám $\geq 300$ G/l (p) } & 0,813 & & & & & \\
\hline
\end{tabular}

Exponenciált koefficiensek

aB́zis: vérlemezkeszám<300 G/1

'Bázis: nő

'Bázis: 1. stádium

dBázis: gradus 1.

'Bázis: algarat

${ }^{*} \mathrm{p}<0,05,{ }^{*} \mathrm{p}<0,01,{ }^{* *}{ }^{*} \mathrm{p}<0,001$

$\mathrm{CI}=$ konfidenciaintervallum

ganatos betegek rosszabb túlélésének a hátterében. Chen és mtsai [34] 270, fej-nyak tumoros beteg adatainak retrospektív elemzése alapján az anaemia, a monocytosis és a thrombocytosis egymástól független rizikófaktorok. $\mathrm{Ez}$ saját vizsgálatunkban is függetlennek bizonyult. Az emelkedett vörösvérsejtszám csökkent 5 éves halálozási kockázattal függött össze. Emellett a betegek vörösvérsejtszámára igazított többváltozós, Cox-féle arányos kockázati regressziós modell azt mutatta, hogy a vérlemezkeszám szignifikáns előrejelzője az 5 éves túlélésnek.

A thrombocytosisra alkalmazott cut-off érték 250400 G/1 között változik a különböző közleményekben [20, 21, 34-38], ami megnehezíti az irodalmi adatok összehasonlítását. Saját adataink alapján a fent részletezett módszerrel választott $300 \mathrm{G} /$ l-es küszöbérték bírt a legnagyobb specificitással és szenzitivitással. A medián vérlemezkeszám 265 G/l volt, ami magyarázhatja az ál- talánosan elfogadott $400 \mathrm{G} / \mathrm{l}$-es thrombocytosisnál alacsonyabb cut-off értéket. Mindemellett megjegyzendő, hogy a vérlemezkeszám laboratóriumi normáltartománya 100-300 G/1 között van, így a statisztikai számításunkkal kapott küszöbérték nem mondható alacsonynak.

Az összefüggés a thrombocytaszám és a túlélés között a különféle közlemények alapján nem egyértelmü. Egy 8 elemzést összehasonlító metaanalízis szerint a thrombocytosis összefüggésbe hozható a rövidebb teljes túléléssel [21]. Pardo és munkacsoportja szignifikáns összefüggést talált az emelkedett vérlemezkeszám és a túlélés között, viszont multivariáns analízisben a thrombocytosis már elvesztette prognosztikai értékét [38]. Érdekes kérdést vet fel, hogy Rachidi és mtsai HNSCC mellett mind alacsonyabb, mind magasabb vérlemezkeszámoknál összefüggést találtak a rosszabb túléléssel, bár thrombocytopenia esetén az eredmény nem volt szignifikáns. 


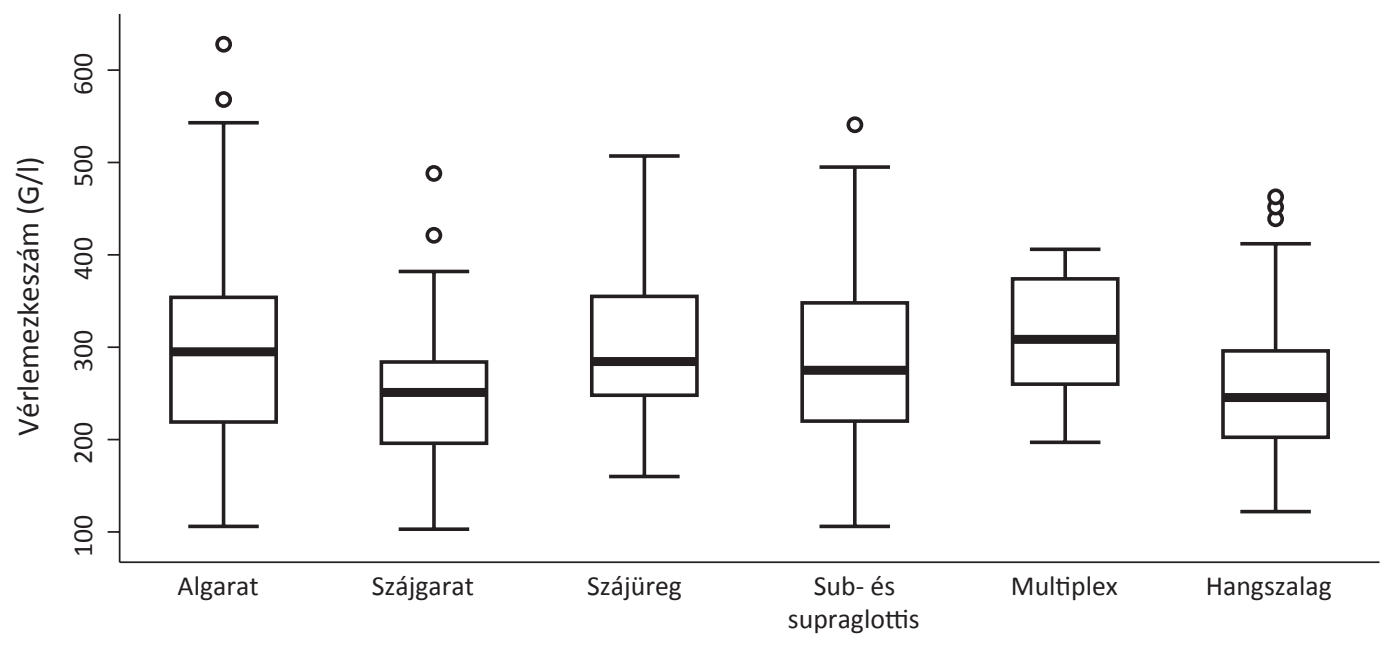

Tumorlokalizáció

3. ábra

Dobozábrák a tumorlokalizáció szerinti vérlemezkeszámról

Vastag vonalak: mediánok; dobozhatárok: interkvartilis terjedelmek; bajszok: felső és alsó végpontok; pontok: kiugró adatok

Vizsgálatuk szerint már a klinikai thrombocytosisnál alacsonyabb értéknél, 315 G/l-es vérlemezkeszám fölött is kétszeres halálozási arány figyelhető meg [36]. Chen munkacsoportja orrgarati tumoroknál észlelt $150 \mathrm{G} / 1$ alatti és $300 \mathrm{G} / 1$ feletti szinteknél szignifikánsan roszszabb túlélést [39]. Saját vizsgálatunkban - mind univariáns, mind multivariáns elemzéssel - szignifikáns összefüggést találtunk a rosszabb túlélés és a kezelés előtti emelkedett vérlemezkeszám között.

A különféle tumorlokalizációk eltérő prognózisával is foglalkozó közlemények algarati daganatoknál találtak szignifikáns összefüggést a vérlemezkeszám és a betegségspecifikus túlélés között [38]. Mások szájüregi tumorokban [20] és az orrgaratban [35] láttak rosszabb túlélést. Vizsgálatunk során mi is eltérő vérlemezkeszámokat találtunk a különféle anatómiai lokalizációkban (3. ábra). A legmagasabb arányban algarati és multiplex lokalizációjú daganatoknál észleltünk küszöbérték feletti thrombocytaszintet, de a tumor elhelyezkedése nem befolyásolta az 5 éves túlélést. Emellett a multivariáns, Cox-féle regressziós elemzés a lokalizáció és a túlélés között szintén nem mutatott szignifikáns összefüggést.

Magasabb vérlemezkeszám mellett a férfinem emelkedett 5 éves mortalitással függött össze, bár az összefüggés nem volt szignifikáns. Lin és mtsai hasonló összefüggést találtak, azaz az emelkedett vérlemezkeszám rövidebb teljes túléléssel járt férfiaknál, de nőknél nem. Génexpressziós analízissel nőknél fokozottabb immunsejtes beszürődést láttak a tumor mikrokörnyezetében, ami magyarázhatja a thrombocytosis prognózisra kifejtett eltérő hatását a nemek között [40]. Más tanulmányok férfiaknál a vérlemezkék fokozottabb aktivitását találták, ami rosszabb daganatos túléléshez vezethet [4l-43].

\section{Következtetés}

Saját vizsgálatunkkal is igazoltuk, hogy a fej-nyaki daganatok esetében hasznos prognosztikai faktornak tünik a tumorhoz társult vérlemezkeszám. A thrombocytaszám eltérő az egyes lokalizációkban, de eredményeink szerint ez nem befolyásolja a túlélést. A vérlemezkeszám olcsón, egyszerüen mérhető, a mérés könnyen ismételhető, emellett daganatos betegeknél rutinszerüen vizsgált paraméter. Tumoros páciensek esetében érdemes nagyobb figyelmet szentelni emelkedett szintjének.

Anyagi támogatás: A közlemény megírása, illetve a kapcsolódó kutatómunka anyagi támogatásban nem részesült.

Szerzôi munkamegosztás: Sz. Zs.: Adatgyưjtés és -feldolgozás, irodalomkutatás, a közlemény megírása. J. V., M. T.: Adatgyújtés, irodalomkutatás. Z. Zs.: Statisztikai elemzés, az adatok értelmezése. M. K.: Irodalomkutatás, kritikai felülvizsgálat. H. F.: A vizsgálat megtervezése, kritikai felülvizsgálat. B. Zs.: A vizsgálat megtervezése, a közlemény írása, kritikai felülvizsgálat. A cikk végleges változatát valamennyi szerző elolvasta és jóváhagyta.

Érdekeltségek: A szerzőknek nincsenek érdekeltségeik.

\section{Irodalom}

[1] Bray F, Ferlay J, Soerjomataram I, et al. Global cancer statistics 2018: GLOBOCAN estimates of incidence and mortality worldwide for 36 cancers in 185 countries. CA Cancer J Clin. 2018; 68: 394-424. [Erratum: CA Cancer J Clin. 2020; 70: 313.]

[2] Ferlay J, Soerjomataram I, Dikshit R, et al. Cancer incidence and mortality worldwide: sources, methods and major patterns in GLOBOCAN 2012. Int J Cancer 2015; 136: E359-E386. 
[3] Wang L, YeErDaoLaiTi Y, Yang G, et al. Effects of regional and general anesthesia on survival in head and neck cancer. Int J Pharmacol. 2018; 14: 528-533.

[4] He Y, Xia T, Bian H, et al. Pretreatment thrombocytosis predicts survival in colorectal cancer. Clin Res Hepatol Gastroenterol. 2016; 40: e59-e60.

[5] Baranyai Zs, Jósa V, Tóth A, et al. Paraneoplastic thrombocytosis in gastrointestinal cancer. Platelets 2016; 27: 269-275.

[6] Josa V, Krzystanek M, Eklund AC, et al. Relationship of postoperative thrombocytosis and survival of patients with colorectal cancer. Int J Surg. 2015; 18: 1-6.

[7] Jósa V, Krzystanek M, Vass T, et al. Thrombocytosis of liver metastasis from colorectal cancer as predictive factor. Pathol Oncol Res. 2015; 21: 991-997.

[8] Hu C, Chen R, Chen W, et al. Thrombocytosis is a significant indictor of hypercoagulability, prognosis and recurrence in gastric cancer. Exp Ther Med. 2014; 8: 125-132.

[9] Li FX, Wei LJ, Zhang H, et al. Significance of thrombocytosis in clinicopathologic characteristics and prognosis of gastric cancer. Asian Pac J Cancer Prev. 2014; 15: 6511-6517.

[10] Cheng J, Zeng Z, Ye Q, et al. The association of pretreatment thrombocytosis with prognosis and clinicopathological significance in cervical cancer: a systematic review and meta-analysis. Oncotarget 2017; 8: 24327-24336.

[11] Cozzi GD, Samuel JM, Fromal JT, et al. Thresholds and timing of pre-operative thrombocytosis and ovarian cancer survival: analysis of laboratory measures from electronic medical records. BMC Cancer 2016; 16: 612.

[12] Feng Z, Wen H, Bi R, et al. Thrombocytosis and hyperfibrinogenemia are predictive factors of clinical outcomes in high-grade serous ovarian cancer patients. BMC Cancer 2016; 16: 43.

[13] Barber EL, Boggess JF, Van Le L, et al. Preoperative thrombocytosis and leukocytosis among ovarian cancer patients are associated with postoperative death. Gynecol Oncol. 2015; 137: 43.

[14] Chadha AS, Kocak-Uzel E, Das P, et al. Paraneoplastic thrombocytosis independently predicts poor prognosis in patients with locally advanced pancreatic cancer. Acta Oncol. 2015; 54: 971978.

[15] Kocak E, Das P, Delclos M, et al. Paraneoplastic thrombocytosis is a significant independent prognostic factor for overall and progression free survival in locally advanced pancreatic cancer. Int J Radiat Oncol Biol Phys. 2014; 90: S365.

[16] Kim M, Chang H, Yang HC, et al. Preoperative thrombocytosis is a significant unfavorable prognostic factor for patients with resectable non-small cell lung cancer. World J Surg Oncol. 2014; 12: 37 .

[17] Wang J, Luo M, Wu H, et al. Preoperative thrombocytosis as a predictor of unfavorable survival in resectable non-small cell lung cancer. J Clin Oncol. 2013; 31(15 Suppl): el8531

[18] Maráz A, Furák J, Varga Z, et al. Thrombocytosis has a negative prognostic value in lung cancer. Anticancer Res. 2013; 33: $1725-1729$

[19] Rajkumar A, Szallasi A. Paraneoplastic thrombocytosis in breast cancer. Anticancer Res. 2013; 33: 4545-4546.

[20] Lu CC, Chang KW, Chou FC, et al. Association of pretreatment thrombocytosis with disease progression and survival in oral squamous cell carcinoma. Oral Oncol. 2007; 43: 283-288.

[21] Takenaka Y, Oya R, Kitamiura T, et al. Platelet count and platelet-lymphocyte ratio as prognostic markers for head and neck squamous cell carcinoma: meta-analysis. Head Neck 2018; 40: 2714-2723

[22] Grambsch PM, Therneau TM. Proportional hazards tests and diagnostics based on weighted residuals. Biometrika 1994; 81: 515-526.

[23] StataCorp. Statistical Software: Release 14. StataCorp LP, College Station, TX, 2015.
[24] Buergy D, Wenz F, Groden C, et al. Tumor-platelet interaction in solid tumors. Int J Cancer 2012; 130: 2747-2760.

[25] Sierko E, Wojtukiewicz MZ. Inhibition of platelet function: does it offer a chance of better cancer progression control? Semin Thromb Hemost. 2007; 33: 712-721.

[26] Gay LJ, Felding-Habermann B. Contribution of platelets to tumour metastasis. Nat Rev Cancer 2011; 11: 123-134.

[27] Nieswandt B, Hafner M, Echtenacher B, et al. Lysis of tumor cells by natural killer cells in mice is impeded by platelets. Cancer Res. 1999; 59: 1295-1300.

[28] Palumbo JS, Talmage KE, Massari JV, et al. Platelets and fibrin(ogen) increase metastatic potential by impeding natural killer cell-mediated elimination of tumor cells. Blood 2005; 105: 178-185.

[29] Placke T, Kopp HG, Salih HR. Modulation of natural killer cell anti-tumor reactivity by platelets. J Innate Immun. 2011; 3: 374-382.

[30] Erpenbeck L, Schön MP. Deadly allies: the fatal interplay between platelets and metastasizing cancer cells. Blood 2010; 115 : $3427-3436$.

[31] Stone RL, Nick AM, McNeish IA, et al. Paraneoplastic thrombocytosis in ovarian cancer. N Engl J Med. 2012; 366: 610-618.

[32] Ludwig H, Van Belle S, Barrett-Lee P, et al. The European Cancer Anaemia Survey (ECAS): a large, multinational, prospective survey defining the prevalence, incidence, and treatment of anaemia in cancer patients. Eur J Cancer 2004; 40: 2293-2306.

[33] Birgegård G, Aapro MS, Bokemeyer C, et al. Cancer-related anemia: pathogenesis, prevalence and treatment. Oncology 2005; 68(Suppl 1): 3-11.

[34] Chen MH, Chang PM, Chen PM, et al. Prognostic significance of a pretreatment hematologic profile in patients with head and neck cancer. J Cancer Res Clin Oncol. 2009; 135: 1783-1790.

[35] Gao J, Zhang HY, Xia YF. Increased platelet count is an indicator of metastasis in patients with nasopharyngeal carcinoma. Tumour Biol. 2013; 34: 39-45.

[36] Rachidi S, Wallace K, Day TA, et al. Lower circulating platelet counts and antiplatelet therapy independently predict better outcomes in patients with head and neck squamous cell carcinoma. J Hematol Oncol. 2014; 7: 65.

[37] Shoultz-Henley S, Garden AS, Mohamed AS, et al. Prognostic value of pretherapy platelet elevation in oropharyngeal cancer patients treated with chemoradiation. Int J Cancer 2016; 138: 1290-1297.

[38] Pardo L, Valero C, López M, et al. The prognostic value of pretreatment platelet count in patients with head and neck squamous cell carcinoma. Auris Nasus Larynx 2017; 44: 313-318.

[39] Chen YP, Chen C, Mai ZY, et al. Pretreatment platelet count as a predictor for survival and distant metastasis in nasopharyngeal carcinoma patients. Oncol Lett. 2015; 9: 1458-1466.

[40] Lin CY, Kwon H, Rangel Rivera GO, et al. Sex differences in using systemic inflammatory markers to prognosticate patients with head and neck squamous cell carcinoma. Cancer Epidemiol Biomarkers Prev. 2018; 27: 1176-1185.

[41] Eidelman O, Jozwik C, Huang W, et al. Gender dependence for a subset of the low-abundance signaling proteome in human platelets. Hum Genomics Proteomics 2010; 2010: 164906.

[42] Drabsch Y, ten Dijke P. TGF- $\beta$ signalling and its role in cancer progression and metastasis. Cancer Metastasis Rev. 2012; 31: $553-568$.

[43] Chen WJ, Jin W, Hardegen N, et al. Conversion of peripheral $\mathrm{CD} 4{ }^{+} \mathrm{CD} 25^{-}$naive $\mathrm{T}$ cells to $\mathrm{CD} 4{ }^{+} \mathrm{CD} 25^{+}$regulatory $\mathrm{T}$ cells by TGF- $\beta$ induction of transcription factor Foxp3. J Exp Med. 2003; 198: 1875-1886.

(Szilasi Zsuzsanna dr., Budapest, Róbert Károly krt. 44., 1134 e-mail: zs.szilasi@gmail.com)

A cikk a Creative Commons Attribution 4.0 International License (https://creativecommons.org/licenses/by/4.0/) feltételei szerint publikált Open Access közlemény. (SID_1) 